\title{
Transfer of technology: a North-South debate?
}

\author{
Reem Anwar Ahmed Raslan \\ Assistant Professor, Faculty of Law, Cairo University
}

The transfer of technology has been mainly subject to the North-South dichotomy where the North is regarded as the principal source of technical knowledge to the South. Nevertheless, as new economic powers emerge in the South, the scene of international technology transfer is changing rapidly. Many South-South endeavors on transfer of technology are on the rise. Thus, a new model of transfer of technology is gaining momentum, in particular the South-South Model of transfer of technology. This paper aims to look at this issue by attempting to answer the following questions: How did South-South cooperation in the field of transfer of technology evolve? How did the rise of the South affect the North-South conflict in the context of transfer of technology? What is the impact of the South-South cooperation in the field of technology transfer on the North?

Keywords: Global South, forced technology transfer, South-South cooperation, technology transfer, triangular cooperation

\section{INTRODUCTION}

At the present time many developing countries look at transfer of technology as a major driving force to achieve sustainable development. This trend is commensurate with the fact that technology has played a paramount role in economic development. In fact, Robert Solow observed that economic growth cannot only be attributed to increases of capital and labor, technological innovation also plays a major role in achieving economic growth. ${ }^{1}$

Historically, developing countries have looked North as a source of technology. Indeed, many international instruments tackle the issue of technology transfer as a North-South issue. These instruments often impose obligations on developed countries towards developing countries. Examples of this trend include a number of WTO agreements (eg the General Agreement on Trade in Services (GATS), ${ }^{2}$ the Agreement on Trade-Related Aspects of Intellectual Property Rights (TRIPS), ${ }^{3}$ the Technical Barriers

1. See MIT, 'Initiative on the Digital Economy, Robert Solow' <http://ide.mit.edu/about-us/ people/robert-solow> accessed 3 October 2020. In 'Technical Change and the Aggregate Production Function' Solow contended that about half of economic growth is not merely a result of increases in capital and labor. Technological innovation, according to Solow, accounts for the rest of the economic growth.

2. See the General Agreement on Trade in Services, Apr. 15, 1994, Marrakesh Agreement Establishing the World Trade Organization, Annex 1B, 1869 U.N.T.S. 183, 33 I.L.M. 1167 (1994) (GATS) Article IV entitled 'Increasing Participation of Developing Countries'.

3. See eg Article 66.2 of the Agreement on Trade-Related Aspects of Intellectual Property Rights, Apr. 15, 1994, Marrakesh Agreement Establishing the World Trade Organization, Annex 1C, 1869 U.N.T.S. 299, 33 I.L.M. 1197 (1994) (TRIPS), which outlines the obligations 
to Trade (TBT) Agreement, the Agreement on the Application of Sanitary and Phytosanitary Measures (the SPS Agreement)).

Nevertheless, as countries of the South start to gain extensive shares in world trade, new windows for South-South Cooperation (SSC) begin to open. To illustrate, the output of the three leading world economies, Brazil, China and India, is about to equal the combined output of traditional leading industrial North countries (Canada, France, Germany, Italy, the United Kingdom and the United States). ${ }^{4}$ South investments in other South countries have increased dramatically. Multinational companies from India, Brazil and South Africa are investing heavily in Africa, Asia and Latin America. ${ }^{5}$ The second largest investor in Sub-Saharan Africa is the Indian conglomerate Tata. ${ }^{6}$ Furthermore, an UNCTAD report provides that South-South trade has overstepped North-South trade in respect of capital goods in many developing countries. ${ }^{7}$ Moreover, there are many cooperation endeavors between countries of the South, such as BRICS, IBSA and COMESA.

First, let us define what is meant by South-South Cooperation. The UN suggested that South-South Cooperation is:

a process whereby two or more developing countries pursue their individual and/or shared national capacity development objectives through exchanges of knowledge, skills, resources and technical know-how, and through regional and interregional collective actions, including partnerships involving Governments, regional organizations, civil society, academia and the private sector, for their individual and/or mutual benefit within and across regions. ${ }^{8}$

But, it is important to note that SSC is not a new endeavor. As we shall see, SSC dates back to the 1950 s, with China and India leading the way. ${ }^{9}$ Also, a number of OPEC countries joined the South-South development trend. For instance, The Kuwait Fund for Arab Economic Development (KFAED), which was set up in 1961, was the first fund of its kind established by a developing country. While the Islamic Development Bank (ISDB) and the Arab Bank for Economic Development in Africa (BADEA) have been active since the mid-1970s. ${ }^{10}$

of developed country Members towards least-developed-country Members in respect of transfer of technology; see also, World Trade Organization, Ministerial Declaration of 14 November 2001, WTO Doc. WT/MIN(01)/DEC/1, 41 ILM 746 (2002) (Doha Declaration) paragraph 37 which addresses transfer of technology to developing countries and calls for recommendations and steps to increase transfer of technology to developing countries.

4. Alvaro Mendez, 'Discussion on the Global South' (2015) 1 Concepts of the Global South Voices from Around the World, Global South Studies Center, University of Cologne, Germany <https://web.archive.org/web/20161026085516/http:/gssc.uni-koeln.de/node/469> accessed 3 October 2020.

5. Hardeep Singh Puri, 'Rise of the Global South and Its Impact on South-South Cooperation' (2010) Development Outreach, World Bank, 8.

6. Ibid.

7. UNCTAD, 'Technology and Innovation Report 2012, Innovation, Technology and SouthSouth Collaboration' (2012) UNCTAD/TIR/2012, 7.

8. Framework of operational guidelines on United Nations support to South-South and triangular cooperation SSC/17/3 (2012). Note by the Secretary-General. High-level Committee on South-South Cooperation. Seventeenth session. New York, 22-25 May 2012, 5.

9. Peter Kragelund, South-South Development (Routledge, Abingdon 2019) 28-42; for a chronology of South-South cooperation, see: The United Nations Office for South-South Cooperation (UNOSSC), <https://www.unsouthsouth.org/about/about-unossc/>.

10. ECOSOC, 'Trends in South-South and Triangular Development Cooperation', Background Study for the Development Cooperation Forum (April 2008), 1. 
At the multilateral level, in 1964 many countries of the South (known as the G77 referring to the number of the countries that initiated the movement at that time) put pressure on the UN in order to accommodate their aspirations of promoting SSC for development. ${ }^{11}$ The creation of the G77 was closely connected to the UN Conference on Trade and Development (UNCTAD). ${ }^{12}$ Thus, it can be fairly said that SSC finds its roots in the Bandung Conference, the Non-Aligned Movement, the creation of the G77 and the UNCTAD. ${ }^{13}$

Ultimately, the UN has established the United Nations Office for South-South Cooperation (UNOSSC) ${ }^{14}$ to, inter alia, promote cooperation among the countries of the South including transfer of technology as well as triangular cooperation. In addition, several international fora have made initiatives in respect of SSC including the UNDP, UNIDO and the UNEP.

As SSC flourishes, many fields of cooperation begin to emerge, including technology transfer. Many emerging economies have achieved a high degree of progress in the field of technology and therefore have the capacity to transfer this knowledge to other countries of the South. In fact, a study has estimated that about 40 percent of the world researchers are in Asia. ${ }^{15}$

Currently, there are many endeavors involving technology transfer between developing countries. The Marrakech Declaration, issued under the auspices of the G77 in 2003, recognized that 'South-South cooperation is not an option but an imperative to complement North-South cooperation'. ${ }^{16}$ The Marrakech Declaration further recognizes that:

... South-South cooperation has experienced successes and failures which are linked, in a broad sense, to the external international environment which influenced development policies and strategies. In the fifties and sixties, South-South cooperation has evolved and been developed in the context of the common struggle of developing countries to reach development and growth. The institutions for South-South cooperation were developed in this period, including G77 and NAM. These and other multilateral organizations, including UNCTAD, UNDP and other institutions of the UN system, helped formulate and articulate southern needs and concerns, and provided a framework for fruitful North-South dialogue and mutually beneficial relationships.$^{17}$

In addition, the Dubai Declaration for the Promotion of Science and Technology in the South (Dubai, 2002), passed in the realm of the Group of 77 South-South High-Level Conference on Science and Technology, called for:

... the promotion and development of knowledge and technology in the South; to encourage the institutions of the South to launch further initiatives to promote knowledge and

11. Kragelund (n 9) 36. For more information see: the Group of 77 at the United Nations $<$ https://www.g77.org/>.

12. Kragelund (n 9) 36.

13. Cheryl McEwan and Emma Mawdsley, 'Trilateral Development Cooperation: Power and Politics in Emerging Aid Relationships' (November 2012) 43 Development and Change 1185, published on behalf of the International Institute of Social Studies, The Hague, 1199.

14. UNOSCC <https://www.unsouthsouth.org/about/about-unossc/>.

15. Singh Puri (n 5) 8.

16. Marrakech Declaration on South-South Cooperation adopted on the occasion of the Highlevel Conference on South-South Cooperation (Marrakech, Kingdom of Morocco, 16-19 December 2003), point 1 .

17. Ibid point 6 . 
technology in developing countries; to harness the potential of human resources, including expatriates, from the South for the benefit of developing countries; to address the challenges associated with brain drain; to create an enduring international environment to ensure the South's access to knowledge and technology; and to promote the central role of the United Nations in removing different barriers faced by the South in the acquisition of knowledge and technology. ${ }^{18}$

The Dubai Declaration indicated several sources for funding: development banks, collaborative programmes and networking. The Dubai Declaration solicited support from several 'international institutions such as FAO, UNCTAD, UNDP, UNESCO and others' to inter alia overcome the digital divide. ${ }^{19}$ In addition, several entities lent support to SSC through, inter alia, triangular cooperation. These entities include: the International Conference on Financing for Development, held in Monterrey in March 2002 and the World Summit on Sustainable Development, held in Johannesburg in August 2002. ${ }^{20}$

Thus, it is important to look at the South-South Model of technology transfer since this area is not well covered in the academic literature. According to an UNCTAD report, there is scarce literature on South-South technological cooperation. In addition, much of the available literature focuses on certain issues such as public health and climate change. ${ }^{21}$ However, recently there has been a growing interest in addressing South-South development cooperation, including the transfer of technology. In particular, the role of China in Africa has received an immense amount of attention in the academic literature. ${ }^{22}$ Much of the emerging research addresses transfer of technology issues in the context of Chinese investments in Africa. ${ }^{23}$ Yet, Chinese involvement in Africa is viewed by skepticism by some commentators as a form of neo-colonialism. ${ }^{24}$ In any event, the assessment of the Chinese involvement in Africa merits another research endeavor. We shall confine our study here to a more generalized outlook of the rising South-South Model of transfer of technology.

This paper is divided into four main sections. Section 1 is the introduction and section 2 addresses preliminary issues related to this study, particularly what is meant by the terms 'South', 'Technology' and 'Transfer of Technology'. Section 3 provides an account of the evolution of the transfer of technology on the international level, outlining the underlying North-South conflict on the issue and looking at the emerging South-South Development Model. Section 4 analyzes the impact of the rise of the South-South Model of transfer of technology on the North. Finally, section 5 is the conclusion.

18. Dubai Declaration for the Promotion of Science and Technology in the South (Dubai, United Arab Emirates, 27-30 October 2002) point 1; UNCTAD, 'Facilitating Transfer of Technology to Developing Countries: A Survey of Home-Country Measures' (2004) United Nations, New York UNCTAD/ITE/IPC/2004/5, 17.

19. Dubai Declaration (n 18); UNCTAD 'Facilitating Transfer of Technology to Developing Countries' (n 18) 17.

20. Marrakech Declaration (n 16) point 10.

21. UNCTAD, 'Technology and Innovation Report 2012' (n 7) 6.

22. The China-Africa Research Initiative of Johns Hopkins University is one of the major academic programs on China-Africa Relations <http://www.sais-cari.org/>.

23. For more information, see ibid.

24. One of the most important works discussing this issue is: Deborah Brautigam, The Dragon's Gift: The Real Story of China in Africa (Oxford University Press, Oxford, UK 2009). 


\section{SOUTH-SOUTH TRANSFER OF TECHNOLOGY: PRELIMINARY ISSUES}

The topic of this paper is South-South transfer of technology. Yet, despite the fact that the terms included in this topic are widely used in the academic literature, the definition of these terms is far from clear. There is no consensus on the terms 'South', 'technology' or 'transfer of technology'. Therefore, it is important to begin our analysis by shedding some light on these ambiguous terms.

\subsection{What constitutes the 'South'?}

Before proceeding with our examination, it is important to determine what is meant by the term 'South'. While this paper does not aim to provide a conclusive definition of the term 'South', it sheds some light on different perspectives on this term. Indeed, the definition of the term 'South' is far from straightforward. Many definitions and connotations have been suggested in this context. The most common connotations are: (Periphery v. the Centre), (Third World v. First and Second World), (Developing v. Developed or Industrialized World) and the (South v. the North). ${ }^{25}$ The connotation (Periphery v. the Centre) was usually employed during colonial times. ${ }^{26}$ The contrast between Third World and First and Second World lost its significance by the end of the Cold War. ${ }^{27}$ In addition, the connotation developing world has become inaccurate due to the rise of many non-Western economies. Thus, a relatively new term is used in that respect which is the 'Global South' ${ }^{28}$ While the term 'South' refers to the fact that most poor countries are in the South. The term 'Global South' encapsulates the underlying forces in the era of globalization. ${ }^{29}$

It is important to note that the classification of countries as 'developed' countries v. 'developing countries' is far from accurate. This classification refers to all European countries, North American countries, Australia/New Zealand and Japan as 'developed' and regards the rest of the world as 'developing'. According to this classification, three states which are included in the top ten economically most powerful states (China, Brazil and India) are considered developing countries. ${ }^{30}$ Thus, there are many serious inaccuracies in this classification.

\section{Kragelund (n 9) 4-7.}

26. See S Batur, 'Center and Periphery', in T Teo (ed), Encyclopedia of Critical Psychology (Springer, New York, NY 2014) 212, pointing out that "Center" and "periphery" are key terms of dependency theories developed in the 1960s and 1970s in order to explain development and underdevelopment'.

27. Heike Pagel and others, "The Use of the Concept "Global South" in Social Science \& Humanities', paper presented at the symposium 'Globaler Süden/Global South: Kritische Perspektiven', Institut für Asien- \& Afrikawissenschaften, Humboldt-Universität zu Berlin, 11 July $2014<$ https://www.academia.edu/7917466/The_Use_of_the_Concept_Global_South_in_ Social_Science_and_Humanities> accessed 24 November 2020; see also Arif Dirlik, 'Global South: Predicament and Promise' (2007) 1 The Global South 12, 13-14, contending that the concept of 'third world' was introduced by Alfred Sauvy in 1952 and was used to contrast the former colonized or neo-colonized world with the modernizing worlds of both capitalism and socialism. 28. Kragelund (n 9) 4-5.

29. Ibid 5 .

30. Tobias Schwartz, 'What I Thought of the Term Global South ... Before I Learned How the Mainstream Uses It' (2015) 1 Concepts of the Global South - Voices from Around the World, Global South Studies Center, University of Cologne, Germany <https://web.archive.org/web/ 20161026085516/http:/gssc.uni-koeln.de/node/469> accessed 3 October 2020. 
The term 'South' emerged in the 1970s, and was to a great extent equivalent, but not identical, to other terms used to describe societies that encountered difficulties in achieving their economic and political goals. ${ }^{31}$ The Brandt Commission reports published in 1980 and 1983 popularized the term 'South'. ${ }^{32}$ It is not clear when the word 'Global' was attached to the term 'South'. Yet, it seems the use of the term 'Global South' was related to the rise of globalization. The UNDP initiative of 2003, 'Forging a Global South', further brought attention to the term 'Global South'. ${ }^{33}$

Nevertheless, the UN uses the term 'Global South' to refer to developing countries which are primarily located in the Southern hemisphere. ${ }^{34}$ To illustrate, the UNDP indicates that the term 'South' is used to refer to developing countries collectively. According to the UNDP, the term 'South' has been used in international relations since the 1970s. The term 'South' rests on the premise that most industrial countries are located in the North. The use of the term, according to the UNDP, does not mean that developing countries can be lumped into a single category. Rather, the term is based on the assumption that developing countries face almost the same vulnerabilities and challenges despite the fact that developing countries may exhibit different economic and social conditions. ${ }^{35}$ Indeed, it is important to note that the term South does not refer to a homogenous group of countries. ${ }^{36}$

Before concluding this part, it is important to note that many commentators have criticized the term (Global South) by indicating that the term is not accurate and that it has political connotations. It has been contended that 'The term Global South functions as more than a metaphor for underdevelopment. It references an entire history of colonialism, neo-imperialism, and differential economic and social change through which large inequalities in living standards, life expectancy, and access to resources are maintained' ${ }^{37}$ In addition, "The use of the phrase "Global South" marks a shift from a focus on development or cultural difference toward an emphasis on geopolitical power relations'. ${ }^{38}$

In addition, it has been observed that economies of the South exhibit different degrees of development, thus, the term 'emerging market economies', or 'emerging markets', for simplicity, was introduced by Antoine van Agtmael in 1981during his tenure as an economist with the International Finance Corporation (IFC). ${ }^{39}$ When the IFC was establishing the first-ever mutual development fund in developing economies, it was suggested that the term 'emerging market fund' be used instead of 'third world equity fund', being less offensive. ${ }^{40}$

Yet, there is no consensus on the definition of the term 'emerging markets'. ${ }^{41}$ Nevertheless, 'emerging market economies' are usually defined through the occurrence

\footnotetext{
31. Dirlik (n 27) 12-13.

32. Ibid.

33. Ibid.

34. Kragelund (n 9) 4.

35. UNDP, 'Forging a Global South: United Nations Day for South-South Cooperation', New York (19 December 2004).

36. Kragelund (n 9).

37. N Dados and R Connell, 'The Global South' (2012) 11 Contexts 12, 13.

38. Ibid 12.

39. International Finance Corporation (IFC), 'Establishing Emerging Markets' <https://www.ifc. org/wps/wcm/connect/corp_ext_content/ifc_external_corporate_site/about+ifc_new/ifc+history/ establishing-emerging-markets $>$ accessed 25 October 2020.

40. Ibid.

41. Ashoka Mody, 'What is an Emerging Market?' (2004), IMF Working Paper, WP/04/177 <https://www.imf.org/external/pubs/ft/wp/2004/wp04177.pdf> accessed 24 November 2020.
} 
of certain characteristics. Carrasco and Williams point out the basic connotations defining emerging market economies. Under this notion, emerging economies can be defined as economies that 'are characterized by significant and rapid economic growth evidenced by rising gross domestic product (GDP) on an aggregate and per capita basis, increased trade volumes, as well as increased foreign reserves' ${ }^{42}$ In addition, another term 'frontier markets' was coined by Farida Khambata, head of IFC's capital-markets department. ${ }^{43}$ The term is used to refer to economies which still have not evolved to reach the status of emerging markets but are promising markets for investment. ${ }^{44}$ Nevertheless, it is contended that the use of the term 'emerging markets' by the IFC is investor driven. ${ }^{45}$

To sum up, it is clear that all these connotations of the term 'South' define the 'South' in relation to the North. ${ }^{46}$ Thus, the North is used as a yardstick by which the progress of the South is measured. This in turn has been reflected in the context of the transfer of technology where the countries of the South were regarded as recipients and the North as donors. Yet, many countries, particularly in the 'emerging South' are starting to emerge as donors for the 'rest of the global South'.

For the purpose of this analysis, we shall use the term 'Global South' in the same sense as used by the UN. We shall also use it interchangeably with the terms 'South' and 'developing countries'. In addition, this article uses the term 'emerging South' to refer to countries of the South which have gained significant economic and political power, while 'the rest of the global South' is used to refer to all other countries of the South which have not achieved considerable economic or political power.

\section{2 'Technology' and 'transfer of technology' revisited}

Before discussing the evolution of the international legal regime governing transfer of technology, it is important to determine what is meant by 'technology' and 'transfer of technology'. Indeed, there is no precise definition of 'technology' or 'technology transfer'. ${ }^{47}$ The definition of these terms often varies according to the discipline or perspective of the authors of these definitions. ${ }^{48}$ Economists, sociologists, anthropologists and management researchers have different accounts regarding technology and technology transfer. ${ }^{49}$

Sazali and Raduan compiled the most notable definitions of technology as well as technology transfer. ${ }^{50}$ We shall not replicate their work here; however, Lan and

42. Enrique R Carrasco and Sean Williams, 'Emerging Economies after the Global Financial Crisis: The Case of Brazil' (2012) 33 Nw. J. Int'l L. \& Bus. 81, 86.

43. Ty McCormick, 'Frontier Markets: A Short History', Foreign Policy (4 March 2013, 12:59

AM) <https://foreignpolicy.com/2013/03/04/frontier-markets-a-short-history/> accessed 25 October 2020.

44. Carrasco and Williams (n 42) 85.

45. Ibid.

46. Kragelund (n 9) 5.

47. Sazali Abdul Wahab, Raduan Rose and Suzana Osman, 'Defining the Concepts of Technology and Technology Transfer: A Literature Analysis' (2012) 5(1) International Business Research 61, 61.

48. Ibid.

49. Ibid.

50. These definitions are reproduced in Abdul Wahab et al. (n 47) 70-71. 
Young identified two main components underlying basic definitions of 'technology' namely:

(i) 'knowledge' or 'technique'; and (ii) 'doing things'; because technology is always connected with obtaining certain results, resolving certain problems, and completing certain tasks by using particular skills, employing knowledge, and exploiting assets. ${ }^{51}$

It must also be noted that there are many classifications of technology. Technology may be codified, such as an operating manual, or uncodified such as tacit knowledge to produce a product. Technology can be embodied, such as technology embodied in a machine, or disembodied such as know-how. Technology can be privately held (proprietary) or publicly held such as patents that have fallen into the public domain. ${ }^{52}$

Whatever, the definition of 'technology' that is adhered to, it is important to note that the main problems related to technology transfer can be rooted in the special nature of 'technology' itself. As Nelson has shown 'Technology has a proprietary aspect and a public good aspect', ${ }^{53}$ where the proprietary aspect gives incentives to firms to innovate in order to reap profits from innovation, while the public good aspect provides the opportunity for society as a whole to benefit from technological advancements. ${ }^{54}$

Furthermore, the market of technology transfer is subject to information asymmetries, where the technology provider is more knowledgeable regarding the value of his technology than the technology buyer. Therefore, technology markets may be prone to market failures, especially in the context of North-South transfer of technology where technology transfer usually does not occur at arm's length. Consequently, many South governments have participated in shaping the technology transfer market to overcome possible market failures. Accordingly, trade and investment policy as well as intellectual property (IP) laws play an important role when designing a technology transfer environment. ${ }^{55}$

The aim of this part was to highlight the terms 'technology' and 'technology transfer' and not to provide a thorough review of these terms. For the purposes of this study, we shall use one of the most established definitions of technology which is the one provided by the UNCTAD Draft International Code of Conduct on the Transfer of Technology (1978-1985) (the Code). The Code defines technology as 'the systematic knowledge for the application of a process that results in the manufacture of a product or the delivery of a service'. ${ }^{56}$ Technology is not a finished product or service as such. ${ }^{57}$

51. P Lan and S Young, 'International Technology Transfer Examined at Technology Component Level: A Case Study in China' (1996) 16 Technovation 277, 278.

52. KE Maskus, 'Encouraging International Technology Transfer' (2004), UNCTAD ICTSD Project on Intellectual Property Rights and Sustainable Development, Issue Paper no. 7, 9.

53. Richard R Nelson, 'What Is Private and What Is Public about Technology?' (1989) 14 Science, Technology, \& Human Values 229.

54. Ibid, In order to resolve this issue, two forms of policy solutions were suggested: adopting a market-based approach by providing incentives to innovate mainly through IPRs; and supporting R\&D through state intervention. See Daniele Archibugi and Kim Bizzarri, 'Committing to Vaccine R\&D: A Global Science Policy Priority' (2004) 33 Research Policy 1657.

55. See in general, Maskus (n 52).

56. UNCTAD, 'Draft International Code of Conduct on the Transfer of Technology, as at the close of the sixth session of the Conference on 5 June 1998' (United Nations, Geneva 1985), United Nations publication, No. TD/Code TOT/47, 20 June, in UNCTAD, Compendium of International Arrangements on Transfer of Technology: Selected Instruments. Relevant Provisions in Selected International Arrangements Pertaining to Transfer of Technology, UNCTAD/ITE/IPC/Misc.5 (2001, (UNCTAD Code), chapter 1, section 1.2.

57. Ibid, chapter 1, section 1.2. 
As for 'transfer of technology', there is no consensus on a definition of transfer of technology ${ }^{58}$ There are different definitions of transfer of technology which often differ from one scientific field to another. ${ }^{59}$ In developed countries transfer of technology is mainly understood as the process of transfer of technology between universities and research institutions to the relevant industry. ${ }^{60}$ The UNCTAD Code defines this term as 'the transfer of systematic knowledge for the manufacture of a product, for the application of a process or for the rendering of a service and [it] does not extend to the mere sale or lease of goods'. ${ }^{61}$

These processes often include, according to the UNCTAD Code:

(a) The assignment, sale and licensing of all forms of industrial property, except for trade marks, service marks and trade names when they are not part of transfer of technology transactions; (b) The provision of know-how and technical expertise in the form of feasibility studies, plans, diagrams, models, instructions, guides, formulae, basic or detailed engineering designs, specifications and equipment for training, services involving technical advisory and managerial personnel, and personnel training; (c) The provision of technological knowledge necessary for the installation, operation and functioning of plant and equipment, and turnkey projects;

(d) The provision of technological knowledge necessary to acquire, install and use machinery, equipment, intermediate goods and/or raw materials which have been acquired by purchase, lease or other means; and (e) The provision of technological contents of industrial and technical co-operation arrangements. ${ }^{62}$

It is commonly observed in the academic literature that the main channels of transfer of technology are: trade, foreign direct investment (FDI), licensing and movement of people. ${ }^{63}$

The UNCTAD Code definitions of 'technology' and 'transfer of technology' are considered one of the most precise and comprehensive definitions in that respect. However, the said definitions are not all inclusive as they were mainly contemplated to apply to cases of transfer of technology between private parties rather than other channels such as intergovernmental technical cooperation. ${ }^{64}$ The reason for that lacuna might lie in the fact that the UNCTAD Code was mainly a result of a developing countries' initiative to counteract restrictive clauses employed by firms from the North operating in the field of technology transfer. ${ }^{65}$

Moreover, it has been recognized that mere possession of technology is not enough to secure development. Instead, building an infrastructure in the host country that is capable of absorbing and developing technology is the key factor in achieving technological development.

58. UNCTAD, 'Transfer of Technology and Knowledge-Sharing for Development: Science, Technology and Innovation Issues for Developing Countries' (2013) UNCTAD/DTL/STICT/ 2013/8, 1-3.

59. See in general: Abdul Wahab et al. (n 47).

60. UNCTAD, 'Transfer of Technology and Knowledge-Sharing for Development' (n 58) 1. See for instance, The Bayh-Dole Act or Patent and Trademark Law Amendments Act (Pub L 96-517, December 12 1980).

61. UNCTAD Code (n 56) chapter 1, section 1.2.

62. UNCTAD Code (n 56) chapter 1, section 1.3.

63. UNCTAD, 'Transfer of Technology and Knowledge-Sharing for Development' (n 58) $15-20$.

64. Ibid 2.

65. See section 3 below. 
Furthermore, one must distinguish between transfer of technology and technology diffusion. ${ }^{66}$ One must also differentiate between importing technology and developing technology. ${ }^{67}$ Technology transfer is different from technology diffusion. Technology diffusion can be generally described as 'the progressive adoption of a particular kind of technology among a given population'. ${ }^{6}$ Technology diffusion includes 'spill-over' effects to other sectors of the economy of a host state. Technology spillover can be defined as the "unintentional technological benefits to firms that come from the research and development efforts of other firms without the costs being shared' ${ }^{69}$ It is also important to note that transfer of technology occurs through agreement between at least two parties, while technology diffusion is not a bilateral transaction. ${ }^{70}$

Another important point to make is the distinction between importing technology and developing technology. ${ }^{71}$ Indeed, it has been recognized that mere possession of technology is not enough to secure development. Instead, building an infrastructure in the host country that is capable of absorbing and developing technology is the key factor in achieving technological development. ${ }^{72}$ It is observed that transfer of technology involves an open choice by the host state regarding whether to import or produce technology. However, for a host state to opt to develop technology it needs to develop a sound absorptive capacity. ${ }^{73}$

Nevertheless, it is important to note that the North-South transfer of technology usually involves state-of-the-art technology. However, if the host country lacks the absorptive capacity to capture the imported technology then a meaningful transfer of technology might not occur. By contrast, South-South transfer of technology involves technology that is often adapted to the needs of developing countries. Host countries are more likely to have the necessary infrastructure to absorb this kind of technology. Yet, South-South transfer of technology has a major drawback as it usually involves outdated technology (technology which is not state of the art). ${ }^{74}$

\section{THE NORTH-SOUTH DEBATE ON TRANSFER OF TECHNOLOGY: PAST AND PRESENT}

In this section, we trace the origins of the North-South conflict on the transfer of technology. We start by looking at the struggle of the South to establish balanced international norms on the transfer of technology. And then we take an initial look at the evolving South-South endeavors on transfer of technology and how these endeavors compare to the North-South Model of transfer of technology.

66. UNCTAD, 'Transfer of Technology and Knowledge-Sharing for Development' (n 58) 2.

67. Ibid.

68. Ibid.

69. Yifei Sun and Peilei Fan, 'Technology Spillover', in International Encyclopedia of Geography: People, the Earth, Environment and Technology (6 March 2017).

70. UNCTAD, 'Transfer of Technology and Knowledge-Sharing for Development' (n 58) 2.

71. Ibid 16.

72. Ibid iii.

73. Ibid 16 .

74. Martin Ingvarsson, 'North-South and South-South Technology Transfer - A Conceptual Framework' (2013) Business Investment Technology Services, UNIDO Working Paper 02/ 2013, sec 3 <https://www.inclusivebusiness.net/node/1459> accessed 11 November 2020. 


\subsection{The evolution of the issue of transfer of technology on the international level}

At the present time, there is no holistic legal framework governing international transfer of technology. Transfer of technology is usually regulated by various international instruments, such as multilateral agreements, regional trade agreements and bilateral agreements.

There have been many attempts to regulate transfer of technology at the international level. ${ }^{75}$ The UN supported numerous international initiatives to facilitate technology transfer to developing countries ${ }^{76}$ with UNCTAD and WIPO further expanding these initiatives. It was clear that the most contentious issue impeding North-South transfer of technology was restrictive business practices. There were many unsuccessful attempts to resolve this conflict at the international level such as the 'Set of Multilaterally Equitable Agreed Principles and Rules for the Control of Restrictive Business Practices' promoted by the $\mathrm{UN}^{77}$ and the UNCTAD Code. ${ }^{78}$ As a result, in the 1970s and 1980s developing countries tried to regulate these restrictive practices by prohibiting the inclusion of certain terms in transfer of technology contracts and regulating excessive royalties. ${ }^{79}$

Nevertheless, the UNCTAD Code is considered to be the most important endeavor in respect of the transfer of technology. Negotiations on the Code took place, on the initiative of developing countries, under UNCTAD auspices between 1976 and $1985 .^{80}$ The most significant complaints regarding restrictive business practices related to grant-back provisions, export prohibitions and non-suitability of the imported technology to local needs. ${ }^{81}$ In our view, the restrictive business practices of developed country firms seems to render the process of transfer of technology a process of commercialization of technology rather than a genuine transfer of technology.

Although the UNCTAD Code was not adopted, it had a great influence on international law and policy regarding transfer of technology until our present time. The influence of the UNCTAD Code is evident in respect of many international instruments. ${ }^{82}$

75. See eg Kiyoshi Adachi, 'UNCTAD's Work on Technology Transfer and Developing Countries' (28 October 2014) WIPO ToT Meeting (28 October 2014) <https://www.wipo.int/ edocs/mdocs/mdocs/en/wipo_ip_ngo_ge_14/wipo_ip_ngo_ge_14_p3.pdf $>$ accessed 5 November 2020, contending that the WIPO Development Agenda represents a significant attempt to formulate international rules on transfer of technology. However, this endeavor received criticism due to its focus on IP as a main vehicle of transfer of technology and as undermining other policies of transfer of technology such as performance requirements, tax incentives and health regulation.

76. Transfer of Technology to Developing Countries [1965] UNGA 92; A/RES/2091 (XX) (20 December 1965).

77. Restrictive Business Practices [1980] UNGA 94; A/RES/35/63 (5 December 1980).

78. Mark Shugurov, 'The TRIPS Agreement, International Technology Transfer and Development: Some Lessons from Strengthening IPR Protection' (2016) 3(1) BRICS Law Journal 90, 105.

79. Ibid 105.

80. In the fall of 1977, the General Assembly decided 'to convene a United Nations conference to negotiate and to take all decisions necessary for the adoption of an international code of conduct on the transfer of technology'. G.A. Res. 32/188, U.N. GAOR, Supp. (No. 45) 117, U.N. Doc. A/32/45 (1977), adopted without vote.

81. Ton JM Zuijdwijk, 'The UNCTAD Code of Conduct on the Transfer of Technology' (1978) 24 McGill Law Journal 562, 563.

82. Representative international instruments include: the CBD and Nagoya Protocol benefits, WHO's GSPoA on Public Health, Innovation and IP, Paragraph 65j of the 2012 Doha 
In the context of the TRIPS Agreement, the UNCTAD Code had an impact on articles $8.2,31(\mathrm{k})$, and 40 of TRIPS. ${ }^{83}$ Yet, these provisions, particularly Article 40, are generally permissive rather than prescriptive in nature except for the right to consultations under Article 40.3. ${ }^{84}$

In particular, Article 40.1 of TRIPS recognizes that licensing practices may have adverse effects on trade or may impede technology transfer/diffusion. Article 40.2 allows Members to prescribe anticompetitive practices which represent abuses of intellectual property rights (IPRs) and take measures to curb these practices provided that such measures are consistent with the other provisions of the TRIPS Agreement. Article 40.2 further provides a non-exhaustive list of such practices, including exclusive grantbacks, clauses preventing validity challenges and coercive package licensing. ${ }^{85} \mathrm{We}$ shall not further elaborate on this issue since it is well covered in the academic literature.

Looking at the evolution of the discourse on transfer of technology, it is clear that the North-South divide continues to shape the international scene of transfer of technology. The North is pushing for a 'competition-based approach' to the transfer of technology and an enhanced IPR protection regime, while the South takes a 'development-based approach' to the transfer of technology and a balanced IPR legal-framework. ${ }^{86}$ In fact, the initiation of the international discourse on transfer of technology by developing countries has been a reaction to the strict protection of IPRs by developed countries. ${ }^{87}$

To sum up, the South is disappointed by the North's stance on transfer of technology at the multilateral level, especially in respect of IPRs. ${ }^{88}$ The North persists in expanding the WTO agenda with little involvement of the South and offers little in the way of assistance to catch up. Indeed, it has been asserted that technical assistance by the North is donor-driven, is hardly sufficient to secure 'capacity building' and is not politically neutral. ${ }^{89}$

Ministerial Mandate, Agreed Recommendation 9c, 2005 Commission on Investment, Technology and related Financial Issues, 2008 Global Strategy and Plan of Action on Public Health, Innovation and Intellectual Property and Recommendation 40 of the 2007 WIPO Development Agenda. See Adachi (n 75).

83. BN Pandey and Prabhat Kumar Saha, 'Competition Flexibilities in the TRIPS Agreement: Implications for Technology Transfer and Consumer Welfare' (2015) 57 Journal of the Indian Law Institute 92, 99.

84. Robert D Anderson, 'Competition Policy and the TRIPS Agreement: More Guidance Needed? Where Might We Look? What Insights from Policy Evolution at the National Level?' (WIPO Symposium on Intellectual Property and Competition Policy, Geneva, 11 May 2010).

85. Ibid.

86. Pandey and Saha (n 83) 96; Shugurov (n 78) 111 highlights that the TRIPS Agreement emphasizes the commercial aspects of technology transfer and pays little attention to the development aspects of technology transfer. See also Zuijdwijk (n 81); Padmashree Gehl Sampath and Pedro Roffe, 'Unpacking the International Technology Transfer Debate: Fifty Years and Beyond' (2012) ICTSD Programme on Innovation, Technology and Intellectual Property, Working Paper, International Centre for Trade and Sustainable Development, Geneva, Switzerland 45.

87. Gehl Sampath and Roffe (n 86) 45.

88. Kevin Gray and Barry K Gills, 'South-South Cooperation and the Rise of the Global South' (2016) 37 Third World Quarterly 557, 558.

89. Yash Tandon, 'Technical Assistance as a Political Instrument', in The Reality of Trade: The WTO and Developing Countries, The North-South Institute (2002) <http://www.nsi-ins. $\mathrm{ca} / \mathrm{wp}$-content/uploads/2012/10/2002-The-Reality-of-Trade-the-Uruguay-Round-andDeveloping-Countries.pdf> accessed 27 October 2020. 
However, the UNCTAD Code was envisaged to apply equally to international transfer transactions whether the transfer takes place between developed and developing countries or between two developing countries. ${ }^{90}$ Yet, since the North has been the primary source of innovation and FDI to the developing world, South-South transfer of technology did not receive much attention at that time.

\subsection{The emerging South-South Model of transfer of technology}

The increasing role played by the South in the technology transfer market, particularly with other countries of the South, raises two questions: How is the South-South Model on transfer of technology different from the North-South Model? Is South-South transfer of technology more beneficial to developing countries than North-South technology transfer?

Before answering these questions, we would like to note at the outset that, when looking at the South-South Model of transfer of technology, it is important to bear in mind that the South-South Model is still developing and therefore it is too early to point to a concrete model. ${ }^{91}$

Another point to take into consideration is that despite the fact that the sentiment that underlies South-South cooperation is the common heritage of the countries of the South in their struggle towards political independence and economic development, this does not mean that the South is a homogeneous group. ${ }^{92}$ As indicated above, the South encompasses countries at different stages of development. Even emerging economies exhibit different models of development cooperation. Thus, we cannot, at this stage, designate a distinctive South-South Model of transfer of technology. Yet, we can look at one of the major South-led development initiatives, namely the Belt and Road Initiative (BRI), to draw some inferences on what a South-South Model might look like.

First, the BRI calls for creating a win-win situation by creating 'prosperous and peaceful community with shared future'. ${ }^{93}$ Accordingly, while China adopts a 'noninterventionist approach' by keeping a low profile in its development cooperation policy, ${ }^{94}$ this has not been the policy of the North. The North's policies usually interfere with the domestic legal system of a given country and tie aid to the fulfillment of certain predetermined conditions.

Second, the North does not leave enough room for the South to participate in setting the development agenda. It has been contended that when the countries of the North provide technical assistance '[they] do so on their own terms; that is, they help implement highly protectionist regimes, without regard for the actual needs of developing nations' 95

90. Zuijdwijk (n 81) 569.

91. Most studies on SSC focus on a particular project in a particular country, therefore we cannot generalize these results.

92. See UNDP, 'Forging a Global South' (n 35).

93. Maggie Xiaoyang Chen and Chuanhao Lin, 'Foreign Investment across the Belt and Road: Patterns, Determinants, and Effects' (2018) Policy Research Working Paper; No. 8607 (World Bank, Washington, DC 2018) 2.

94. See eg, Cátia Miriam Costa, 'The Words of the Belt and Road Initiative: A Chinese Discourse for the World?', in Francisco José BS Leandro and Paulo Afonso B Duarte (eds), The Belt and Road Initiative: An Old Archetype of a New Development Model (Palgrave Macmillan, Singapore 2020).

95. Rochelle Cooper Dreyfuss, 'TRIPS-Round II: Should Users Strike Back?' (2004) 71 U. Chi. L. Rev. 21, 25. 
This one-sided approach is particularly evident in the TRIPS Agreement, which requires harmonization of IP-related laws across WTO Members. Yet, in contrast to the practice of many developed countries, China, in the context of the BRI in particular, does not seek harmonization among BRI countries. ${ }^{96}$ Specifically, the Joint Communique of the Leaders' Roundtable of the 2nd Belt and Road Forum for International Cooperation states that:

All states are equal partners for cooperation that respects openness, transparency, inclusiveness and [a] level playing field. We respect [the] sovereignty and territorial integrity of each other and affirm that each country has the right and primary responsibility to define its development strategies in accordance with its national priorities and legislation. ${ }^{97}$

Third, as for dispute settlement, North countries seek to resolve the international transfer of technology trade-related issues through the WTO Dispute Settlement Body (DSB) ${ }^{98}$ while China has assumed a pacifist approach regarding dispute settlement in the context of the BRI, which emphasized resort to amicable diplomatic means of dispute settlement. However, recently China started to explore developing its own dispute settlement fora, such as the China International Commercial Court (CICC). ${ }^{99}$

Turning to question two, is the South-South Model on transfer of technology more beneficial for the South than the North-South Model? Again, it is too early to provide a comprehensive assessment of the issue and we believe that the answer will be different in each case. However, we can make some initial remarks.

It has been noticed that there is a divide between countries of the South, namely, the divide between the 'emerging South' and the 'rest of the South'. It is suggested that the benefits of SSC are chiefly harnessed by the 'emerging South' to the detriment of the 'rest of the South'. ${ }^{100}$ Research has produced mixed results in respect of the beneficial results of South-South transfer of technology. ${ }^{101}$ In fact, it has been asserted that:

... just being South-South does not ensure that such exchanges will not be subject to the same types of limitations present in [the] North-South dimension. Conflicting priorities,

96. Carolyn Dong and Simin Yu, 'One Belt One Road - China's New Outbound Trade Initiative', DLA Piper (18 January 2016) <https://www.dlapiper.com/en/singapore/insights/publications/2016/ 01/chinas-new-outbound-trade-initiative/> accessed 19 October 2020.

97. Joint Communique of the Leaders' Roundtable of the 2nd Belt and Road Forum for International Cooperation, Belt and Road Cooperation: Shaping a Brighter Shared Future, 27 April 2019, Beijing, China, point 6 .

98. See for instance the WTO Case: China - Certain Measures on the Transfer of Technology, DS549.

99. Jiangyu Wang, 'Dispute Settlement in the Belt and Road Initiative: Progress, Issues, and Future Research Agenda' (2020) 8 The Chinese Journal of Comparative Law 4. Wang states that ' $\ldots$ the CICC also has to be understood in the context of China's general ambivalent approach to law: law and legalized dispute resolution are of instrumental use only and will be employed when China believes that they can protect China's interests and help China gain legitimacy in the international society', ibid 18.

100. OS Dahi and F Demir, 'South-South and North-South Economic Exchanges: Does It Matter Who Is Exchanging What and With Whom?' (2017) 31 Journal of Economic Surveys 1449,1450 . Dahi and Demir provided that the share of the rest of the South in world manufacturing exports of high-technology and skill-intensive products stayed at or below 1 percent and has never exceeded 2 percent of world trade, while that of the emerging South has increased from 2 percent in 1962 to 55 percent in 2012, exceeding the share of the North (45 percent), ibid, 1454.

101. Ibid 1449-50. 
differing development narratives, and problems in the suitability of local technologies to other Southern countries' needs remain as problematic in South-South exchanges as in North-South. ${ }^{102}$

To sum up, it has been claimed that:

South-South co-operation (SSC) and North-South co-operation (NSC) arise from different historical backgrounds and have their own distinctive features. Over the past 60 years, they developed in parallel without much contact as two separate traditions of development co-operation. However, SSC and NSC share a common goal: to increase the well-being of people in developing countries. Despite differences in the terms they use, actors of NSC and SSC also share a set of principles for development co-operation. ${ }^{103}$

Furthermore, Scoones et al. point out that one cannot adopt a simplistic view of SSC by viewing it as a utopic model of development or as a form of neo-imperialism. ${ }^{104}$ Accordingly, it remains to be seen whether a South-South Model of transfer of technology will materialize as a model distinct from the North-South Model or will it play a complementary role to the traditional North-South Model. The next section will attempt to inform this discussion.

\section{THE IMPACT OF THE SOUTH'S RENAISSANCE ON THE NORTH: DOMINATION OR COOPERATION?}

With the rise of the 'emerging South' new players entered the transfer of technology field. Countries of the 'emerging South' started to invest and transfer technology to other countries of the South. It is widely held that the rise of SSC is likely to have a great impact on the development cooperation scene. ${ }^{105}$ These changes to the traditional North-South Model of transfer of technology have alarmed the North. ${ }^{106}$ It is suggested that the reaction of the North to these changes has evolved in the following sequence: 'from fear to cooperation and attempted capture'. ${ }^{107}$ We observe this trend in the context of the impact of South-South technology transfer on the North.

\subsection{The Rise of the 'South' as a technology exporter: initial reactions by the North}

In this section, we will follow up on the North-South debate on technology transfer. In particular, the increased growth of the role of many South countries as technology exporters has evoked a sharp reaction from the North. Specifically, developed countries countered by raising a new concept to challenge South policies in respect of trade in technology, namely the concept of 'forced technology transfer'. The North is worried about the rise of South-South technology transfer since it may have the

102. Ibid 1471.

103. Piera Tortora, 'Common Ground between South-South and North-South Co-operation Principles' OECD Development Cooperation Directorate, Issue Brief (October 2011).

104. I Scoones and others, 'A New Politics of Development Cooperation? Chinese and Brazilian Engagements in African Agriculture' (2016) 81 World Development 1.

105. Dahi and Demir (n 100) 1450.

106. Ibid 1468.

107. Kragelund (n 9). 
effect of creating rivals not only in the market of a Southern country exporting technology but also in the global market, especially in South markets where South technology is deemed to be more appropriate to the needs of these markets. ${ }^{108}$

The concept of 'forced technology transfer' is employed, in our view, to preserve the North's dominance in the technology market, in other words, to defend the NorthSouth Model of technology transfer. This raises important questions: What is meant by forced technology transfer? Why was this issue raised in this particular time?

In May 2018, a high-level meeting between Ambassador Robert E Lighthizer, United States Trade Representative, Mr Hiroshige Seko, Minister of Economy, Trade and Industry of Japan, and Mrs Cecilia Malmström, European Commissioner for Trade, was held. The parties issued a 'Joint Statement on Technology Transfer Policies and Practices'. The representatives condemned what they referred to as 'unfair', 'non-market based' laws and policies regarding the transfer of technology. In particular, the Joint Statement provides that: 'The Ministers confirmed their shared view that no country should require or pressure technology transfer from foreign companies to domestic companies, including, for example, through the use of joint venture requirements, foreign equity limitations, administrative review and licensing processes, or other means' ${ }^{109}$

The Ministers voiced their concern that these laws and policies will cause distortion to international trade, present unfair competitive disadvantages to their citizens and industries and have a negative effect on innovation. The Ministers further pledged their intentions to work together as well as with other like-minded partners in order to combat the alleged unfair trade practices in respect of technology transfer, including recourse to the WTO Dispute Settlement Body to resolve such disputes. ${ }^{110}$

In our opinion, the issue of 'forced technology transfer' is a very vague concept. First, it is hard to provide a clear definition of the term 'forced technology transfer'. ${ }^{111}$ After all, the TRIPS Agreement has clearly stated that IPRs are an important vehicle for technology transfer, usually through IP licensing. Article 7 of TRIPS provides that the "protection and enforcement of intellectual property rights should contribute to the promotion of technological innovation and to the transfer and dissemination of technology'. ${ }^{112}$ Furthermore, Article 8 of the TRIPS Agreement states that:

1. Members may, in formulating or amending their laws and regulations, adopt measures necessary to protect public health and nutrition, and to promote the public interest in

108. Thomas Hout and Pankaj Ghemawat, 'China vs the World: Whose Technology Is It?', Harvard Business Review, December $2010<\mathrm{https} / / \mathrm{hbr}$. org/2010/12/china-vs-the-worldwhose-technology-is-it> accessed 21 November 2020.

109. Joint Statement on Trilateral Meeting of the Trade Ministers of the United States, Japan and the European Union, Annexed Statement 2: Joint Statement on Technology Transfer Policies and Practices (31 May 2018).

110. Ibid.

111. See, Julia Ya Qin, 'Forced Technology Transfer and the US-China Trade War: Implications for International Economic Law' (29 September 2019), Wayne State University Law School Research Paper No. 2019-61. SSRN: <https://ssrn.com/abstract=3436974> or $<$ http://dx.doi.org/10.2139/ssrn.3436974> accessed 20 October 2020; however, the EU employs a definition of the term 'forced technology transfer' which refers to a situation 'where foreign operators are directly or indirectly forced to share their innovation and technology with the state or with domestic operators', The European Commission, 'WTO-EU's Proposals on WTO Modernization' (5 July 2018) The EU Concept Paper', I.B(i) <https://trade.ec.europa. eu/doclib/docs/2018/september/tradoc_157331.pdf> accessed 4 December 2020.

112. TRIPS Article 7. 
sectors of vital importance to their socio-economic and technological development, provided that such measures are consistent with the provisions of this Agreement.

2. Appropriate measures, provided that they are consistent with the provisions of this Agreement, may be needed to prevent the abuse of intellectual property rights by right holders or the resort to practices which unreasonably restrain trade or adversely affect the international transfer of technology. [Emphasis added]

It is clear from Article 8 that WTO Members are free to adopt measures to remedy situations of the abuse of IPRs as well as to prevent anticompetitive practices or practices that have an adverse effect on transfer of technology. While this provision is binding on both developed and developing countries, the exact modalities for transfer of technology, especially through IPRs, is subject to a heated controversy. Indeed, what the rights and obligations of both technology donors (usually from the North) and technology importers (usually South countries) are is far from clear.

The answer to this question differs from jurisdiction to jurisdiction. North countries demand stronger protection of IPRs and are vocal about any regulatory measures that could, in their view, negatively impact these rights. South countries want to put in place a regulatory system to ensure that a real process of technology transfer shall occur and not just a process of commercial sale of technological products. Thus, the use of many regulatory measures by South countries such as performance requirements, control of restrictive clauses in technology transfer transactions and administrative review of contracts involving transfer of technology are rules which are usually imposed by transfer of technology laws in many countries of the South. ${ }^{113}$

The position of the North on regulatory measures used by the South countries is puzzling. Is a patent law requiring disclosure of an invention as a ground for granting patent protection 'forced technology transfer'? Are 'local working requirements' in some patent laws forced technology transfer? Is imposing measures such as performance requirements as a condition to enter a market in the South considered a restriction on trade? In the same vein, is the reverse true? In particular, can one consider restrictive conditions imposed by technology exporters (usually private firms from the North) concerning the prohibition of the modification of technology to suit local conditions or giving a degree of control of the facility of the technology importer to the technology exporter, impediments to trade by forcing technology importers to accept terms that are not conducive to the transfer of technology?

In respect of the disclosure of the invention as a ground for patent registration, Article 29 of the TRIPS Agreement provides that WTO Members must require patent applicants to disclose the invention in a sufficiently clear and complete manner so as to enable a person skilled in the art to carry out the invention. WTO Members may also require patent applicants to declare the best mode to carry out the invention - the 'best mode' requirement. Is disclosure of an invention forced technology transfer?

Do compulsory licenses, which are allowed by Article 31 of the TRIPS Agreement, constitute forced technology transfer? Is a state exercising its rights under Article 31 to issue a compulsory license to remedy anticompetitive practices by a patent holder considered forced technology transfer?

Moreover, the North tends to seek to resolve North-South conflict in respect of transfer of technology through the multilateral trading system, specifically through

113. For an overview of host developing country measures regarding transfer of technology see: Michael Waibel and William P Alford, 'Technology Transfer' (Vol. IX, 8 October 2011), in R Wolfrum (ed), Max Planck Encyclopedia of Public International Law, 801-14 SSRN: $<$ https://ssrn.com/abstract=2507143> accessed 7 November 2020. 
the WTO Dispute Settlement Body, ${ }^{114}$ while South countries resort to other international organizations and bodies which they perceive to be more accommodative of their concerns such as the UNCTAD. This double-track regulation of international transfer of technology issues was present from the early days of the inclusion of the transfer of technology debate in the international agenda. We believe that this 'double-track' approach in shaping the international transfer of technology legal regime will lead to a fragmented and incoherent result.

In addition, we note that North countries usually use the market as a benchmark to determine whether a technology transfer transaction is fair. However, this approach is problematic for a number of reasons: it is well established that there is a difference between government intervention to create a market where no market will exist absent government intervention and government intervention to influence the competition conditions in an established market. This issue has been recognized in the case of measures employed to promote green energy. ${ }^{115}$ This observation can be generalized to the transfer of technology in other fields. Furthermore, North countries provide support for private firms in their attempts to acquire technology from universities and research institutions. To illustrate, the US government allows universities and other non-profit institutions that are supported by Federal Funds to hold IPRs to their inventions (private ownership of publicly funded research). ${ }^{116}$ Thus, transfer of technology in the North is not entirely governed by the market.

To sum up, 'forced technology transfer' is a vague term that might go against the objectives of IPRs and FDI, as recognized in international instruments, of facilitating technology transfer. In addition, there are many success stories of cooperation in the form of North-South joint ventures, ${ }^{117}$ which means that the North-South technology transfer can be a ground of cooperation rather than confrontation. Indeed, it has been contended that 'the greater openness today of both developed and developing economies to foreign trade and investment means that the best opportunities for growth in sales and profits are increasingly available to companies of all origins'. ${ }^{118}$ We shall elaborate on this point in the next section.

\subsection{The rise of the 'Triangular Model' of transfer of technology}

As shown above, the reaction of the North to the rise of SSC has evolved, as asserted by Peter Kragelund, in the following sequence: 'from fear to cooperation and attempted capture'. ${ }^{119}$ The North has moved beyond apprehension of SSC and is increasingly seeking opportunities to cooperate with the South. 'Triangular Cooperation' $(\mathrm{TrC})$ is also gaining momentum in the international development cooperation field.

114. Joint Statement on Trilateral Meeting (n 109).

115. For more details see: Appellate Body Reports, Canada - Certain Measures Affecting the Renewable Energy Generation Sector/Canada - Measures Relating to the Feed-in Tariff Program, WT/DS412/AB/R/WT/DS426/AB/R, adopted 24 May 2013, DSR, 2013, para 5.185. 116. Patent and Trademark Law Amendments Act (Pub. L. 96-517, December 12, 1980) (The Bayh-Dole Act).

117. Thomas Hout and Pankaj Ghemawat, 'Tomorrow's Global Giants? Not the Usual Suspects', Harvard Business Review, November 2008 <https://hbr.org/2008/11/tomorrows-global-giants-notthe-usual-suspects> accessed 21 November 2020.

118. Ibid.

119. Kragelund (n 9). 
The UN's working definition of $(\mathrm{TrC})$ is 'Southern-driven partnerships between two or more developing countries, supported by a developed country(ies)/or multilateral organization(s), to implement development cooperation programmes and projects'. ${ }^{120}$ Another definition of $\operatorname{TrC}$ states that 'Triangular development cooperation has been interpreted as OECD/DAC donors or multilateral institutions providing development assistance to Southern governments to execute projects/programmes with the aim of assisting other developing countries'. ${ }^{121}$

The OECD defines $\operatorname{TrC}$ as follows "when countries, international organisations, civil society, private sector, private philanthropy and others work together in groups of three or more, to co create flexible, cost-effective and innovative solutions for reaching the SDGs'. ${ }^{122}$ TrC can be viewed as a bridge between traditional NSC and SSC. ${ }^{123}$

It is argued that $\mathrm{TrC}$ evolved as traditional donors, mostly led by the Development Assistance Committee (DAC) of the OECD have started to coordinate aid mechanisms with each other and have also started to include former aid recipients as resource providers. ${ }^{124}$ Indeed, the rise of new donors from the South has had a great impact in respect of foreign aid, a domain which was traditionally dominated by Western donors. The term 'new donors' is usually used to refer to these countries. ${ }^{125}$

A number of initiatives by the G8/G20, the UN, the World Bank and the IMF, as well as the EU and the DAC have emerged in order to try to involve emerging South donors. The most notable of these initiatives include the Development Cooperation Forum (DCF) established by the UN General Assembly under the auspices of ECOSOC in 2007, which was envisaged to act a forum for both donors and recipients rather than focusing on donors. The DAC launched an outreach initiative to emerging non-DAC donors in 2005. The G8 together with the OECD and the World Bank held a conference on 'Emerging Donors in the Global Development Community' in 2006. In addition, bilateral aid agencies, such as the UK's Department for International Development (DFID), have started to engage emerging donors in its activities. ${ }^{126}$

Moreover, the UN as well as the UNDP have further played a substantial role in promoting SSC and TrC. In 1974, a special unit (the predecessor of the United Nations Office for South-South Cooperation (UNOSSC), was established within the UNDP by the UN General Assembly to promote technical cooperation among developing countries. ${ }^{127}$ In 1978, the Buenos Aires Plan of Action (BAPA) for Promoting

120. Framework of operational guidelines on United Nations support to South-South and triangular cooperation (SSC/17/3 (2012). Note by the Secretary-General. High-level Committee on South-South Cooperation. Seventeenth session. New York, 22-25 May 2012, 5.

121. ECOSOC, Trends in South-South and Triangular Development Cooperation (n 10), 3.

122. OECD, 'Triangular Co-operation: Why Does it Matter?' (2018) $3<$ https://www.oecd.org/ dac/dac-global-relations/_Triangular\%20Booklet\%20A5\%20pages.pdf> (accessed 5 November 2020).

123. Bogota Statement, 'Towards Effective and Inclusive Development Partnerships', High Level Event on South-South Cooperation and Capacity Development, Bogota (25 March 2010) $1<$ http://www.un.org/en/ecosoc/newfunct/pdf/bogota-statement-final.pdf> accessed 19 October 2020.

124. Jin Sato, 'Triangular Cooperation in East Asia: Challenges and Opportunities for Japanese Official Development Assistance' (2018) 49(3) IDS Bulletin 111, 112.

125. Ibid 111-12.

126. McEwan and Mawdsley (n 13) 1189-90.

127. The UN has established a 'High-level Committee on South-South Cooperation' which is a subsidiary body of the UN General Assembly. The substantive secretariat of the High-Level Committee is the UN Office for South-South Cooperation (UNOSSC). The UNOSSC serves 
and Implementing Technical Cooperation among Developing Countries was adopted by the UN General Assembly. ${ }^{128}$

In 2009, a high-level UN Conference on SSC was held in Nairobi, Kenya, which resulted in the adoption of the Nairobi Outcome Document. ${ }^{129}$ The Nairobi Outcome Document stressed that 'South-South cooperation is not a substitute for, but rather a complement to, North-South cooperation'. ${ }^{130}$ Thus, we can deduce that NSC is seen as the principal model of cooperation between states. SSC, according to the Nairobi outcome document, plays only a complementary role in cooperation between states.

In contrast to the SSC Model, the North still takes the position of dominance in respect of its cooperation with the South, with emphasis on the division of states as donors and recipients. ${ }^{131}$ This is evident since $\operatorname{TrC}$ can be reported as Official Development Assistance (ODA) to the OECD DAC Creditor Reporting System (CRS). ${ }^{132}$ Also, it is argued that self-interest is one of the most important motives of countries of the North in TrC. Particularly, since the new ODA Charter of 2015 stipulated, for the first time, securing 'national interests' as an important goal of development cooperation. ${ }^{133}$ It has been asserted that the political nature of development as well as the uneven power relations between involved participants is de-emphasized in the academic literature. ${ }^{134}$

Furthermore, it is argued that $\operatorname{TrC}$ is still dominated by the North who tries to replicate the traditional North-South Development Model. It is argued that in the context of $\mathrm{TrC}$, it is the North that sets the agenda according to its own priorities, with no or limited participation by the South partners, particularly the aid recipients. ${ }^{135}$ Why then will TrC be chosen over the traditional NSC? This seems to entail that the North aims to 'capture' the phenomenon of SSC by promoting the concept of TrC.

It is interesting to see how the South will react to TrC. In fact, it might seem counterintuitive that China has been recently undertaking a trilateral approach in the context of development cooperation by seeking to partner with the UN and traditional Western donors. ${ }^{136}$ Thus, the evolution of SSC, in particular in the field of transfer of technology, as well as the effect of the rising SSC on the North is an area which is rife for further academic research.

\section{CONCLUSION}

The SSC renaissance has presented a challenge to the North-dominated development model, including the North-South Model of transfer of technology. Southern economic

to enhance and coordinate South-South Cooperation as well as Triangular Cooperation. The United Nations Office for South-South Cooperation (UNOSSC) <https://www.unsouthsouth. org/about/about-unossc/>.

128. Ibid.

129. Nairobi outcome document of the High-level United Nations Conference on South-South Cooperation, G.A. Res. 64/222 (December 21 2009).

130. Ibid (Article 14).

131. Singh Puri (n 5) at 8.

132. OECD, Triangular Co-operation (n 122) 10.

133. Sato (n 124) 120.

134. McEwan and Mawdsley (n 13) 1187.

135. Ibid 1192, 1197-8.

136. Sato (n 124) 121-2. 
powers are increasingly replacing the North in the field of international transfer of technology. The North was initially alarmed by the new developments and then it changed course by attempting to capture the new trend of SSC through promoting an alternative cooperation model, namely, TrC. Nevertheless, it remains to be seen whether the South-South Development Model will develop into a distinctive model or remain complementary to the North-South Model. To conclude, what can be deduced so far is that SSC has the potential for dramatically changing international aid and technical assistance relations in the near future.

\section{BIBLIOGRAPHY}

Abdul Wahab S, Rose R and Osman S, 'Defining the Concepts of Technology and Technology Transfer: A Literature Analysis' (2012) 5(1) International Business Research 61.

Adachi K, 'UNCTAD's Work on Technology Transfer and Developing Countries', WIPO ToT Meeting (28 October 2014) <https://www.wipo.int/edocs/mdocs/mdocs/en/wipo_ip_ngo_ge_14/ wipo_ip_ngo_ge_14_p3.pdf $>$ accessed 5 November 2020.

Anderson RD, 'Competition Policy and the TRIPS Agreement: More Guidance Needed? Where Might We Look? What Insights from Policy Evolution at the National Level?' (WIPO Symposium on Intellectual Property and Competition Policy, Geneva, 11 May 2010).

Archibugi D and Bizzarri K, 'Committing to Vaccine R\&D: A Global Science Policy Priority' (2004) 33 Research Policy 1657.

Batur S, 'Center and Periphery', in T Teo (ed), Encyclopedia of Critical Psychology (Springer, New York, NY 2014).

Bogota Statement, 'Towards Effective and Inclusive Development Partnerships', High Level Event on South-South Cooperation and Capacity Development, Bogota (25 March 2010) $<$ http://www.un.org/en/ecosoc/newfunct/pdf/bogota-statement-final.pdf > accessed 19 October 2020.

Brautigam D, The Dragon's Gift: The Real Story of China in Africa (Oxford University Press, Oxford, UK 2009).

Carrasco ER and Williams S, 'Emerging Economies after the Global Financial Crisis: The Case of Brazil' (2012) 33 Nw. J. Int'l L. \& Bus. 81.

Chen MX and Lin C, 'Foreign Investment across the Belt and Road: Patterns, Determinants, and Effects', Policy Research Working Paper; No. 8607 (World Bank, Washington, DC 2018).

Costa CM, 'The Words of the Belt and Road Initiative: A Chinese Discourse for the World?', in FJBS Leandro and PAB Duarte (eds), The Belt and Road Initiative: An Old Archetype of a New Development Model (Palgrave Macmillan, Singapore 2020).

Dados N and Connell R, 'The Global South' (2012) 11 Contexts 12.

Dahi OS and Demir F, 'South-South and North-South Economic Exchanges: Does It Matter Who Is Exchanging What and With Whom?' (2017) 31 Journal of Economic Surveys 1449.

Dirlik, A, 'Global South: Predicament and Promise' (2007) 1 The Global South 12.

Dong C and Yu S, 'One Belt One Road - China's New Outbound Trade Initiative', DLA Piper (18 January 2016) <https://www.dlapiper.com/en/singapore/insights/publications/2016/01/ chinas-new-outbound-trade-initiative/> accessed 19 October 2020.

Dreyfuss RC, 'TRIPS-Round II: Should Users Strike Back?' (2004) 71 U. Chi. L. Rev. 21.

Dubai Declaration for the promotion of science and technology in the South (Dubai, United Arab Emirates, 27-30 October 2002)

ECOSOC, 'Trends in South-South and Triangular Development Cooperation', Background Study for the Development Cooperation Forum (April 2008).

European Union (EU) 'Concept paper: WTO modernization' (2018) <http://trade.ec.europa.eu/ doclib/docs/2018/september/tradoc_157331.pdf> accessed 4 December 2020.

Gehl Sampath P and Roffe P, 'Unpacking the International Technology Transfer Debate: Fifty Years and Beyond' (2012) ICTSD Programme on Innovation, Technology and Intellectual 
Property, Working Paper, International Centre for Trade and Sustainable Development, Geneva, Switzerland.

Gray K and Gills BK, 'South-South Cooperation and the Rise of the Global South' (2016) 37 Third World Quarterly 557.

Hout $\mathrm{T}$ and Ghemawat P, 'China vs the World: Whose Technology Is It?', Harvard Business Review, December $2010<$ https://hbr.org/2010/12/china-vs-the-world-whose-technology-isit $>$ accessed 21 November 2020.

Hout T and Ghemawat P, 'Tomorrow's Global Giants? Not the Usual Suspects', Harvard Business Review, November 2008 <https://hbr.org/2008/11/tomorrows-global-giants-notthe-usual-suspects> accessed 21 November 2020.

Ingvarsson M, 'North-South and South-South Technology Transfer - A Conceptual Framework' (2013) Business Investment Technology Services, UNIDO Working Paper 02/2013 <https:// www.inclusivebusiness.net/node/1459> accessed 11 November 2020

International Finance Corporation (IFC), 'Establishing Emerging Markets' <https://www.ifc.org/ $\mathrm{wps} / \mathrm{wcm} / \mathrm{connect} / \mathrm{corp} \_$ext_content/ifc_external_corporate_site/about+ifc_new/ifc+history/ establishing-emerging-markets> accessed 25 October 2020

Joint Communique of the Leaders' Roundtable of the 2nd Belt and Road Forum for International Cooperation, Belt and Road Cooperation: Shaping a Brighter Shared Future, 27 April 2019, Beijing, China.

Joint Statement on Trilateral Meeting of the Trade Ministers of the United States, Japan and the European Union, Annexed Statement 2: Joint Statement on Technology Transfer Policies and Practices (31 May 2018).

Kragelund P, South-South Development (Routledge, Abingdon 2019).

Lan P and Young S, 'International Technology Transfer Examined at Technology Component Level: A Case Study in China' (1996) 16 Technovation 277.

Marrakech Declaration on South-South Cooperation adopted on the occasion of the High-level Conference on South-South Cooperation (Marrakech, Kingdom of Morocco, 16-19 December 2003).

Maskus KE, 'Encouraging International Technology Transfer' (2004), UNCTAD ICTSD Project on Intellectual Property Rights and Sustainable Development, Issue Paper no. 7.

McCormick T, 'Frontier Markets: A Short History', Foreign Policy (4 March 2013, 12:59 AM) $<$ https://foreignpolicy.com/2013/03/04/frontier-markets-a-short-history/> accessed 25 October 2020.

McEwan C and Mawdsley E, 'Trilateral Development Cooperation: Power and Politics in Emerging Aid Relationships' (November 2012), 43 Development and Change 1185, published on behalf of the International Institute of Social Studies, The Hague.

Mendez A, 'Discussion on the Global South' (2015) 1 Concepts of the Global South - Voices from Around the World, Global South Studies Center, University of Cologne, Germany <https://web.archive.org/web/20161026085516/http:/gssc.uni-koeln.de/node/469> accessed 3 October 2020.

MIT, 'Initiative on the Digital Economy, Robert Solow' <http://ide.mit.edu/about-us/people/ robert-solow> accessed 3 October 2020.

Mody A, 'What is an Emerging Market?' (2004), IMF Working Paper, WP/04/177 <https:// www.imf.org/external/pubs/ft/wp/2004/wp04177.pdf> accessed 24 November 2020.

Nelson RR, 'What Is Private and What Is Public about Technology?' (1989) 14 Science, Technology, \& Human Values 229.

OECD, 'Triangular Co-operation: Why Does it Matter?' (2018) <https://www.oecd.org/dac/ dac-global-relations/_Triangular\%20Booklet\%20A5\%20pages.pdf> (accessed 5 November 2020).

Pagel H and others, 'The Use of the Concept "Global South" in Social Science \& Humanities', paper presented at the symposium 'Globaler Süden/Global South: Kritische Perspektiven', Institut für Asien- \& Afrikawissenschaften, Humboldt-Universität zu Berlin, 11 July 2014 $<$ https://www.academia.edu/7917466/

The_Use_of_the_Concept_Global_South_in_Social_Science_and_Humanities> accessed 24 November 2020. 
Pandey BN and Saha PK, 'Competition Flexibilities in the TRIPS Agreement: Implications for Technology Transfer and Consumer Welfare' (2015) 57 Journal of the Indian Law Institute 92.

Qin JY, 'Forced Technology Transfer and the US-China Trade War: Implications for International Economic Law' (29 September 2019), Wayne State University Law School Research Paper No. 2019-61. SSRN: <https://ssrn.com/abstract=3436974> or <http://dx. doi.org/10.2139/ssrn.3436974> accessed 20 October 2020.

Sato J, 'Triangular Cooperation in East Asia: Challenges and Opportunities for Japanese Official Development Assistance' (2018) 49(3) IDS Bulletin 111.

Schwartz T, 'What I Thought of the Term Global South ... Before I Learned How the Mainstream Uses It' (2015) 1 Concepts of the Global South - Voices from Around the World, Global South Studies Center, University of Cologne, Germany <https://web.archive.org/web/ 20161026085516/http:/gssc.uni-koeln.de/node/469> accessed 3 October 2020.

Scoones I and others, 'A New Politics of Development Cooperation? Chinese and Brazilian Engagements in African Agriculture' (2016) 81 World Development 1.

Shugurov M, 'The TRIPS Agreement, International Technology Transfer and Development: Some Lessons from Strengthening IPR Protection' (2016) 3(1) BRICS Law Journal 90.

Singh Puri H, 'Rise of the Global South and Its Impact on South-South Cooperation' (2010) Development Outreach, World Bank.

Sun Y and Fan P, 'Technology Spillover', in International Encyclopedia of Geography: People, the Earth, Environment and Technology (6 March 2017).

Tandon Y, 'Technical Assistance as a Political Instrument', in The Reality of Trade: The WTO and Developing Countries, The North-South Institute (2002) <http://www.nsi-ins.ca/wp-content/ uploads/2012/10/2002-The-Reality-of-Trade-the-Uruguay-Round-and-Developing-Countries. pdf $>$ accessed 27 October 2020

Tortora P, 'Common Ground between South-South and North-South Co-operation Principles' OECD Development Cooperation Directorate, Issue Brief (October 2011).

UNCTAD, 'Draft International Code of Conduct on the Transfer of Technology, as at the close of the sixth session of the Conference on 5 June 1998' (United Nations, Geneva 1985), United Nations publication, No. TD/Code TOT/47, 20 June, in UNCTAD, Compendium of International Arrangements on Transfer of Technology: Selected Instruments. Relevant Provisions in Selected International Arrangements Pertaining to Transfer of Technology, UNCTAD/ITE/IPC/Misc.5 (2001).

UNCTAD, 'Facilitating Transfer of Technology to Developing Countries: A Survey of HomeCountry Measures' (2004) United Nations, New York, UNCTAD/ITE/IPC/2004/5.

UNCTAD, 'Technology and Innovation Report 2012, Innovation, Technology and South-South Collaboration' (2012) UNCTAD/TIR/2012.

UNCTAD, 'Transfer of Technology and Knowledge-Sharing for Development: Science, Technology and Innovation Issues for Developing Countries' (2013) UNCTAD/DTL/ STICT/2013/8.

UNDP, 'Forging a Global South: United Nations Day for South-South Cooperation', New York (19 December 2004).

Waibel M and Alford WP, 'Technology Transfer' (Vol. IX, 8 October 2011), in R Wolfrum (ed), Max Planck Encyclopedia of Public International Law, 801-14. SSRN: <https://ssrn.com/ abstract $=2507143>$ accessed 7 November 2020.

Wang J, 'Dispute Settlement in the Belt and Road Initiative: Progress, Issues, and Future Research Agenda' (2020) 8 The Chinese Journal of Comparative Law 4.

Zuijdwijk TJM, 'The UNCTAD Code of Conduct on the Transfer of Technology' (1978) 24 McGill Law Journal 562. 